\title{
W podwojonym cieniu Zapiski z etnografii życia
}

\begin{abstract}
Abstrakt
Artykuł jest próbą przedstawienia idei etnografii życia rozumianej jako opowieść formatywna o kształtowaniu własnej tożsamości zarówno w sensie diachronicznym, jak i z punktu widzenia kluczowych metafor, które przenikają trajektorię całego życia. Etnografia życia to rodzaj intelektualnej i emocjonalnej wiwisekcji, autoterapii narracyjnej, która objawia konteksty i momenty kluczowe dla budowania tego, co nazywa się biografią naukową. Kluczową metaforą prezentowanej opowieści jest „cień podwojony” - cień przemijania najbliższych i życie w cieniu powojennej rzeczywistości PRL.
\end{abstract}

Słowa kluczowe: etnografia, pamięć, metafora, tożsamość, narracja, wiwisekcja.

\section{The Doubling of Shadow. Notes from an Ethnography of Life}

\begin{abstract}
The paper is an attempt to present the idea of an ethnography of life understood as a formative narrative on the shaping of one's identity diachronically as well as from the perspective of key metaphors penetrating the trajectory of the whole life. Ethnography of life is a kind of intellectual and emotional vivisection, a reflexive autotherapy which highlights the different contexts and crucial moments that shape what we often call a scientific biography. The key metaphor of this story is "the doubling of shadow" - the passing of the loved ones, and life in the shadow of the postwar reality of the People's Republic of Poland.
\end{abstract}

Keywords: ethnography, memory, metaphor, identity, narrative, vivisection.

* SWPS Uniwersytet Humanistycznospołeczny. 
Rocznice skłaniają do refleksji. To banalne stwierdzenie traci posmak trywialności w momencie, kiedy rocznicowe „obchody” potraktujemy jak najbardziej prywatnie - jako swoisty le point de capiton, moment retrospektywnego zakotwiczenia samego siebie w trajektorii życia. Niekoniecznie musi się to wiązać z psychoanalityczną interpretacją w stylu Lacanowskim, choć takie skojarzenia nasuwają się jako pierwsze (zob. Lacan 2013). Innym tropem, którym chciałbym podążać w niniejszym tekście, jest ścieżka etnograficznej wiwisekcji i próba rzucenia światła na - zwykle wypierane z zawodowej codzienności - owo „zapikowanie” znaczącego i znaczonego, moment, który sprawia, że sam sobie jawię się jako obiekt stabilny: Wojciech Burszta. Ale stabilność ta, by użyć frazy z tytułu książki Zygmunta Baumana, wynika z „życia w kontekstach” (Bauman, Kubicki, Zeidler-Janiszewska 2009). Dla mnie tym kontekstem jest tytułowy „cień podwojony”.

Metafora cienia jest z pewnością dobrze zakotwiczona w toposie naszej kultury i dość już spetryfikowana, ale nie znajduję lepszej, aby owo „przesłonięcie” towarzyszące mojemu życiu oddać za pomocą innej. Swego czasu trafiłem na następujący passus w jednym z tekstów teologicznych:

Wśród licznych biblijnych metafor znajdziemy obraz cienia. Występuje on w wielu miejscach Starego i Nowego Testamentu. Cień jest przestrzenią pozbawioną światła, tworzącą się wtedy, gdy między źródłem światła a rzeczą przez nie oświetlaną znajdzie się przedmiot nieprzezroczysty i niedopuszczający promieni świetlnych. Innymi słowy, cień to ciemnawa smuga padająca od oświetlonego przedmiotu (ciemne odbicie tej rzeczy) w kierunku przeciwnym do źródła światła. Zgodnie z tym fizykalnym ujęciem możemy mówić - także i w Biblii - o cieniu góry, drzewa czy sylwetki ludzkiej. Cieniowi można nadać jednak sens przenośny. Może on oznaczać miejsce zasłonięte przed źródłem światła (miejsce cieniste, zacienione, ocienione, zacienie), a przez to miejsce schronienia przed skwarem, miejsce wytchnienia, miły chłód, ochłodę; ubocze, ustronie, ukrycie, ochronę, opiekę, a nawet protekcję. Cień to także brak światła, a więc ciemność, mrok, noc. Cień może wyrażać zło, złą stronę charakteru, plamę, skazę, zmazę, niesławę, podejrzenie; zły wygląd, wielkie wychudzenie, resztkę zmizerniałego, zabiedzonego człowieka. Cień jest też obrazem śmierci (cień śmierci), ducha zmarłego, upiora, widma, zjawy, mary, majaki. Za pomocą cienia można oddać najmniejszy ślad, odrobinę, okruch, źdźbło, cząsteczkę, resztkę czegoś (np. cień dawnej wielkości), nieuchwytną postać czegoś, ułudę, złudę, mrzonkę, błahostkę oraz przeciwieństwo rzeczywistości, nieudolne, wprowadzające w błąd naśladownictwo czegoś, zaledwie obraz, słabe wyobrażenie, namiastkę. Cień obrazuje też rzeczy znikome, szybko przemijające, nietrwałe, nikłe, wątłe, kruche, łamliwe, marne (Kalbarczyk 2004: 7). 
Cień podwojony to mrok, jaki na mnie padał, i który był mi jednocześnie schronieniem w tym sensie, że stanowił źródło bycia-w-świecie przesłonięte cieniem obsesji śmierci rodziców i - jednocześnie - próbą rozjaśnienia mroków „socjalistycznej szczęśliwości”, w której przyszło mi dorastać w latach sześćdziesiątych i siedemdziesiątych XX w. Cień podwojony to walka ze smutkiem, jaką podjąłem, aby stać się tym, kim jestem dzisiaj. Etnografia życia, jeśli poważyć się na stosowanie tego terminu do jednostki, do samego siebie, byłaby niczym innym, jak swoistym raportem $\mathrm{z}$ tych zmagań. Jest ona zarówno wierna chronologii, jak i przekracza ten wymiar, podobnie jak w wypadku wierności sobie $\mathrm{w}$ ramach tożsamości narracyjnej.

Pojmowanie własnego życia jako opowieści nie jest naddatkiem, czymś przypadkowo się pojawiającym, ale znajduje się w przestrzeni pytań, na które jedyną odpowiedzią jest spójna narracja. To, kim jestem dzisiaj, zawdzięczam „czasowaniu" świadomości, kim byłem kiedyś, ale także - dokąd zmierzam, choćbym nawet nie wierzył do końca, iż jestem w stanie to przewidzieć.

Bliski mi Paul Ricoeur dodaje ze swej strony, iż problem tożsamości osobowej można w ogóle prawomocnie sformułować dopiero wtedy, kiedy weźmiemy pod uwagę czasowy wymiar ludzkiego istnienia. Tożsamość osobowa jako zarówno idem, jak i ipse wyraża trwałość charakteru. Jednak dopiero wierność sobie w dochowaniu danego przez nas słowa wskazuje na ostateczny rozdział między trwałością siebie i trwałością tego samego. Owa biegunowość bierze się stąd, iż tożsamość narracyjna wpływa na ustanowienie pojęcia tożsamości osobowej, która jest swoistą średnią miarą między biegunem charakteru (zejście się idem i ipse) a biegunem zachowania siebie, na którym bycie sobą uwalnia się od bycia tym samym.

„[P]ytanie o człowieka zdolnego do różnych działań, to według Ricoeura pytanie o to kto może mówić, działać, a także o to, kto może o sobie opowiadać, a ponadto kto może uczynić się odpowiedzialnym za własne czyny" (Ricoeur 2003a: 131; wyróżnienie $\mathrm{w}$ oryginale). Właśnie w tym kontekście znajduje swoje właściwe miejsce pytanie o narracyjność. Dotyczy ono „relacji do czasu jednocześnie podmiotu mówiącego i podmiotu działającego - relacji, której czasowość zostaje stematyzowana przez opowiadanie” (tamże). „[W] niejednej opowieści ten-który-jest-sobą poszukuje tożsamości właśnie na szczeblu całego życia" (Ricoeur 2003b: 191).

W roku 2017 kończę sześćdziesiąty rok życia. To, co jeszcze niedawno wydawało się niewyobrażalne, odsuwane jako abstrakcyjny moment wyobrażonej przyszłości, a więc przejście do kategorii wiekowej bliższej końca drogi aniżeli jej początków i środka, staje się faktem egzystencjalnym, bolesnym i radosnym jednocześnie. Uświadamia i prowokuje do podsumowań, każe uważnie wsłuchiwać się w przeszłość, niepokoi i zachęca do nadziei, że to tylko kolejny etap, że wiele jeszcze do zrobienia, że to nie pora na reasumpcje ostateczne, a jedynie zapis „po drodze" czyniony, może mądrzejszy niż wcześniej, a może wcale nie? 
Patrzę na obraz namalowany przez mojego najstarszego przyjaciela, niezmiennie od kilku dziesięcioleci najbliższego druha, Krzysztofa „Qubę” Kubaczewskiego. To portret mojego Ojca, Józefa Burszty, powstały z okazji uczczenia przez nas (bo Quba miał status „drugiego syna”) dnia, kiedy ten kończył 60 lat. Jest rok 1974, sam mam lat siedemnaście, człapię z klasy do klasy w podrzędnym liceum poznańskim i po raz pierwszy uświadamiam sobie z całą mocą, że Ojciec jest starszym człowiekiem, że jest śmiertelny, jak wszyscy najbliżsi, jak moja Matka, jak bliższa i dalsza rodzina. Bo wszyscy są ode mnie starsi, urodzeni w epoce zamierzchłej, w przeszłości wręcz niewyobrażalnie odległej.

To jest point de capiton, który po raz pierwszy uświadamia mi, że smutek - wypierany w różny sposób, ale ciągle obecny jak natrętne myśli - towarzyszący mi od lat, że przekonanie o nieuchronności przemijania są ściśle związane z wiekiem rodziców. Dzisiaj nie jest niczym szczególnym, o czym przekonują edukacyjne realia, iż generacje rodziców szkolnych pociech wielce są zróżnicowane, nie dziwią ojcowie (ale i matki), którzy w latach mojego dzieciństwa z pewnością zostaliby zakwalifikowani do grona dziadków i starszych opiekunów... Dla dziecka w latach sześćdziesiątych i nastolatka pierwszej połowy lat siedemdziesiątych XX w., żyjącego w Poznaniu i obserwującego rodziców rówieśników, uświadomienie sobie, że cień wieku rodziców (w momencie moich urodzin Ojciec miał 43 lata, Matka 40) jest naprawdę głęboki i przenikający, stało się elementem codziennego myślenia, obsesją, ale i zarzewiem buntu przeciwko wyrokom czasu.

Mam pełną świadomość niebezpieczeństw wiążących się z adaptacyjnym podejściem do przeszłości, że projektując dzisiejsze stany świadomości na realia, kiedy nasze wyobrażenia były zupełnie inne (adekwatne do wieku i sytuacji), dokonujemy nadużyć. Ale mam jednocześnie pewność owego momentu kluczowego, który sprawił, że wybrałem taką, a nie inną drogę życiową. Bo - wybrałem ją dla Rodziców, Ojca przede wszystkim, dlatego, by - jednocześnie - powstrzymać upływ czasu i zatopić się w jego uwodzicielskim nurcie. Uciec, by odnaleźć się inaczej i gdzie indziej.

Patrzę na portret Ojca, sam kończąc lat sześćdziesiąt. Jednocześnie mija lat trzydzieści od jego śmierci w lipcu 1987 r. Przyglądam się Ojcu i sobie w sposób symultaniczny, mieszający czasy, niegodzący się z rachubą linearną, ale i tę ostatnią jakoś przecież respektując i uwzględniając. Mam pewność, że to, co zwiemy życiem, a co wiąże się z poczuciem, że wiele rzeczy - przeszłych i obecnych - dzieje się jednocześnie, nie jest jedynie mało istotnym dodatkiem do zawodowej biografii, ale istotnym wymiarem jej kształtu i profilu. Słowem, mam nadzieję pokazać, że istnieje coś takiego jak „etnografia życia”. Opowieść o podwojonym cieniu, jaki barwę tego życia ukształtował. Po latach lepiej rozumiem, dlaczego jedną z ważniejszych lektur mojej młodości była Rzeźnia numer pięć Kurta Vonneguta i podróżujący „między czasami” jej bohater (Vonnegut 2013). Billy Pilgrim, bohater wspomnianej powieści, zostaje zmuszony do przeniesienia się w inny wymiar rozumienia czasu, aby „zrozumieć”, co wydarzyło się w Dreźnie feralnego dnia (bombardo- 
wanie miasta przez aliantów 13 lutego 1945 r.) i jak widzieć sens życia, jeśli on w ogóle daje się ustalić. Powtórzy zatem za Tralfamadorianami, pewnym plemieniem z kosmosu, że wszystkie momenty z przeszłości, teraźniejszości i przyszłości istniały zawsze i będą istnieć równocześnie. Ludzkie życie kieruje się zasadą nieoznaczoności. Jedyne, co jest pewne na tym świecie, to potrzeba jego opowiedzenia.

Etnografia życia nie jest wyrazem żadnego determinizmu. Raczej podpowiada, sugeruje i zachęca do wiwisekcji, która - jak wiadomo - zawsze jest dokonywana na żywym organizmie, ergo także na istocie myślącej. Etnografia życia to bytowanie wśród innych, owe różne rodzaje socjalizacji/enkulturacji, które oswajają nas z realiami, przemieniają pragnienia w rzeczywistość, by ta znów - zwrotnie - była pretekstem, by się od niej dystansować, wychodzić poza jej ograniczenia i wyroki.

Wychowałem się w rodzinie, można rzec, w jakimś sensie imigranckiej. Oboje rodzice urodzili się - odpowiednio w roku 1914 i 1917 - w jednej wsi, Grodzisku Dolnym koło Leżajska, skąd w realiach powojennego budowania nowego życia udali się do Poznania. To miasto stało się naszą ojczyzną lokalną, ale ojczyzna ideologiczna zdawała się ciągle tkwić w galicyjskich korzeniach, krajobrazach i rozbudowanych więziach rodzinnych (matka miała dziesięcioro rodzeństwa, ojciec czworo). Starsza siostra Halina urodziła się w trakcie drugiej wojny światowej (1943 r.) jeszcze w Grodzisku, młodsza, Małgorzata, już w Poznaniu w roku 1946. Wreszcie, po jedenastu latach, po wielu staraniach, zwątpieniach i zawiedzionych nadziejach, przychodzę na świat ja, pierwszy i jedyny syn, urodzony, jak stoi w pewnym dokumencie „z matki Marceliny i ojca docenta”.

Jako dzieci zawsze jesteśmy otoczeni osobami starszymi, to oczywiste. W moim wypadku owo bycie zawsze w gronie najmłodszych bardzo się jednak przedłużało. W linii krewniaczej większość moich kuzynek i kuzynów była przynajmniej dziesięć albo piętnaście lat starsza, czułem się więc zmuszony do życia trochę na uboczu albo wręcz przeskakiwałem o jedną kategorię wiekową, aby znaleźć rówieśników do zabaw. Weźmy choćby rodzeństwo ojca, to które było „pod ręką”, zawędrowawszy w latach czterdziestych do Wielkopolski. Brat Stanisław (zachęcony przez młodszego Józefa, mojego ojca, osiedlił się z rodziną w Tarnowie Podgórnym koło Poznania), urodził się w roku 1906; siostra Aniela (na tej samej zasadzie osiedliła się w Luboniu pod Poznaniem) - w roku 1909. „Środkowy”, ukochany wujek Wojtek, mój imiennik, przyszedł na świat w roku 1913. Najmłodsza z rodzeństwa Balbina, która, podobnie jak Wojciech, została w rodzinnej wsi, to początek lat dwudziestych. Wszyscy oni mieli szybko dzieci, które w roku 1957, kiedy przyszedłem na świat, osiągały dorosłość albo były nastolatkami dalekimi od chęci zajęcia się gówniarzem. Wszyscy też byli dziećmi chłopskimi, dla których byłem co najwyżej „profesorskim synkiem”, miejskim paniczykiem i uprzywilejowanym przedstawicielem inteligencji, klasy im nieznanej zupełnie.

Podobnie z rodzeństwem mamy, z dwoma małymi wyjątkami. Siostry Apolonia (po wojnie osiadła w Lesznie) i Weronika (do końca życia w Grodzisku) miały 
„późnych” synów, mniej więcej moich rówieśników. Zygfryd i Stanisław urodzili się w roku 1955 i 1956 i nietrudno się domyślić, że to z nimi utrzymywałem najściślejsze więzi, wędrując w każdej wolnej chwili między Lesznem, Grodziskiem Dolnym i Poznaniem. To z nimi spędzałem wiele dni świątecznych, chodząc po kolędzie, obserwując zwyczaj straży przy grobie Chrystusa, tzw. turki grodziskie w okresie Wielkanocy, szalałem w sylwestrowe noce w Lesznie, wynosząc do lasu bramy i furtki gospodarzy, namiętnie grałem w pokera, budowałem amatorskie miniskocznie narciarskie, odwiedzałem w wakacje letnie - jak mawiałem - „sto osób najbliższej rodziny", pomagałem w żniwach itd. Każdorazowe spotkanie z nimi wiązało się wszakże z podróżami - odpowiednio - 500 i 70 kilometrów. Oni nie mogli być ze mną na co dzień. Cała reszta generacyjnych rówieśników była starsza i kiedy i oni zaczęli obrastać w dzieci, ja dopiero wkraczałem w dorosłość jako licealista, gdzie ponownie - $\mathrm{z}$ racji, iż zacząłem edukację $\mathrm{w}$ wieku sześciu lat stałem się beniaminkiem, o rok młodszym od koleżanek i kolegów z V Liceum Ogólnokształcącego w Poznaniu.

Dlaczego o tym piszę, dlaczego uważam to moje rodzinne between and betwixt za ważny element etnografii życia? Po pierwsze, od kiedy tylko pamiętam frapował mnie upływ czasu i starzenie się. Dziesiątki najbliższych mi osób urodziło się jeszcze w czasach cesarza Franciszka Józefa, od matki i ojca poczynając, w dorosłość wchodzili w okresie drugiej wojny światowej bądź już byli dojrzałymi ludźmi w tych latach, a w drugiej dekadzie sześćdziesiątych, kiedy budowałem mozolnie swój świat „znaczących innych”, stawali się babciami i dziadkami. Żyłem wprawdzie w Poznaniu, ale moją ojczyzną intymną było Grodzisko Dolne, które traktowałem jako także i moją wieś rodzinną. Powroty do Galicji były przede wszystkim podróżami sentymentalnymi, zarówno w sensie przestrzennym, jak i czasowym. Dzisiaj już wiem, że nieświadomie stawałem się etnografem w tym sensie, że za każdym razem wysiadając z pociągu w Przeworsku albo z ojcowego Wartburga, a później Fiata 125p, i witając się z bliskimi w Grodzisku, wkraczałem w inny świat, inne tempo życia, odmienną wyobraźnię i zupełnie nieznane w Poznaniu opowieści. Natychmiast przechodziłem na grodziską gwarę, i - jak mawiał ojciec - na dobre wsiąkałem w realia mi najbliższe, włącznie z - to także jego określenie - „wsiąkaniem w alkohol”1. Kiedy zamieszkiwałem w tzw. „starej chałupie”, w której urodził się mój ojciec, a wówczas już właściwie pełniącej rolę spichrza, miałem wrażenie, że nie tyle w naiwnym sensie ludomańskiego zachwytu, ale naprawdę wędruję w czasie. To tam słuchałem sowicie zakrapianych i zakąszanych grodziskimi wędlinami i serem opowieści wujka Wojtka i jego żony Pawli (Pauliny), tam słuchaliśmy Wolnej Europy i tam właśnie uświadamiałem sobie, że fascynuje mnie czas i jego trajektoria. Wędrując z kolei po rodzinnych zagonach na Mokrzance (tak nazywa się część Grodziska, gdzie osiedli Bursztowie), wypytywałem Wojtka, gdzie

\footnotetext{
1 Ojcu także zawdzięczam zasadę, którą wpajał mi w życie, iż „Bursztowie uwielbiają alkohol, ale się w nim nie kochają". Jak mogę, tak jej przestrzegam...
} 
pasał krowy mój ojciec, gdzie tęsknił za ucieczką za horyzont własnego, ciasnego orbis interior i jak to było możliwe, że tylko on istotnie opuścił na dobre swój matecznik i ojcowiznę.

Wsłuchiwałem się w opowieści starszych ludzi - namiętnie, godzinami i przy każdej okazji. Wśród starszych czułem się chez soi, oni mieli mi coś istotnego do przekazania. Od nich nauczyłem się, że życie tu i teraz jest chwilą, która wpisuje się w cały ciąg podobnych momentów i pięknie jest, kiedy można sięgać pamięcią po jak najwięcej z nich, nawet tych przykrych, okrutnych i bolesnych. Ale słuchanie starszych miało i to do siebie, że zawsze widziałem ich twarze, gesty i mimikę, że to były twarze, gesty i mimika ludzi, którzy - i tego się obawiałem obsesyjnie - już niedługo odejdą z tego świata, ergo mojego życia.

Doskonale pamiętam te momenty także z domu, moje obawy o życie rodziców, kiedy niedomagali, coś im dolegało. Mając starszych rodziców, jest się - śmiem twierdzić - naznaczonym piętnem ich kruchości i obawami, że mogą odejść. Mama od lat leczyła się psychiatrycznie, jako że akurat dla niej przenosiny z orbis interior Grodziska Dolnego do zimnego uczuciowo, „suchego” towarzysko inteligencko-profesorskiego kręgu poznańskiego, w którym świetnie odnalazł się ojciec, było tragedią. Nigdy nie przyjęła się w kulturze Poznania, zawsze czuła się tutaj obco, jak, by użyć grodziskiego określenia, „zawsze przywłoka”, a nie „swoja”. Wiedziałem o tym, niekiedy wstydziłem z tego powodu, ale tym bardziej bacznie obserwowałem, jak długo jeszcze będzie dawać sobie radę.

Wielokrotnie, po nocach, wsłuchiwałem się w ich oddechy, sprawdzałem, czy wszystko w porządku, dyskretnie obserwowałem, czy coś złego się z nimi nie dzieje, cisza z gabinetu ojca albo pokoju matki była potencjalnym znakiem czegoś niedobrego. To był ten wielki cień, jaki położył się na moim dzieciństwie, cień przemijania, nieuchronności upływu lat, zmiany na gorsze, wreszcie śmierci. Cień, którego nigdy się już nie pozbyłem, towarzyszy mi nieustannie. To on sprawia, że mam zdiagnozowaną pewną postać depresji wymagającej od lat zażywania tabletek. Wiem, że już się z niej nie wyzwolę z pewnością, bo cień śmierci idzie ze mną krok w krok i nie sposób mu umknąć, jak przecież każdemu z nas, który wypełnia schemat kolejnych rites de passage.

Paradoksalne jest to, że śmierć ojca w roku 1987 i matki w 1998, to były także swoiste momenty wyzwolenia, ostatecznego spełnienia się obaw, że to, o czym myślałem tyle lat, właśnie się dokonało, że nie będę już dłużej musiał żyć w cieniu życia ku śmierci rodziców. Bardzo trudno to uczucie opisać, ale było realne, namacalne, w jakiś sposób właśnie wyzwalające. Oswajałem je zresztą od lat, wracając do kart Rzemiosła życia Cesare Pavese, do dzisiaj mojej formatywnej lektury. Jedna z notatek włoskiego pisarza brzmi: „Twoje przeświadczenie o tym, że jakim kto był jako dziecko, takim będzie i jako człowiek dorosły, że «nośność mostu» nigdy nie ulegnie zmianie, zatraciło wszelką ponurość, przemieniło się $\mathrm{w}$ poszukiwanie fantastycznych początków chwili-wieczności” (Pavese 1972: 352). 
Życie wśród starszych i brak, poza dwoma kuzynami, rówieśników w rodzinie nie sprawiało wszakże, że moje życie naznaczone było wyłącznie smutkiem i przygnębieniem. Nic podobnego. Chwile refleksyjnego bycia wśród świadków historii i depozytariuszy pamięci rodzinnej nie przesłaniały mi przecież codzienności i nie obezwładniały. Wręcz przeciwnie - napędzały aktywność wszelaką, może nawet jako formę zapomnienia i oderwania się od rodzinnych spraw i trosk. Wiedziałem, że „życie jest gdzie indziej”, że muszę uciekać od smutku i oderwać od obsesji przemijania bliskich.

Moje dzieciństwo i młodość to przede wszystkim namiętne oddawanie się sportowi. Zacząłem karierę bokserską w milicyjnym (sic!) klubie Olimpia Poznań, dostałem się pod opiekę wspaniałego trenera, Jana Arskiego, już wówczas starszego pana, który prowadził mnie w walkach tzw. pierwszego kroku. Po jednej z nich (wygranej 2:1) nie udało się w domu ukryć pokiereszowanej twarzy i ojciec błyskawicznie „wypisał” mnie z klubu. Kolarstwo mnie męczyło, łucznictwo nudziło, hokej na trawie nieco śmieszył, pozostawała więc piłka nożna. Jako że edukacja pod koniec szkoły podstawowej i całe niemal liceum nie interesowała mnie przesadnie, tak organizowałem sobie czas, aby trenować w wielu klubach naraz. W pewnym momencie, w latach 1969-1971 byłem piłkarzem kilku poznańskich klubów: Olimpii, Energetyka, Sanu, Surmy i Lecha Poznań. Potem wybrałem młodzików i juniorów młodszych Kolejorza, grając w nich m.in. z późniejszą wielką gwiazdą Lecha i Bundesligi, Mirosławem Okońskim. Po latach tak pisałem o tym niebywałym doświadczeniu:

Piłka nożna, jedna z hegemonicznych dzisiaj dyscyplin sportu, dla każdego z nas pełna jest takich momentów, które na zawsze zapamiętamy. Dotyczy to także wspomnień i nostalgicznych ewokacji z czasów, kiedy samemu było się uczestnikiem boiskowej communitas. Sam mógłbym o tym opowiadać w nieskończoność, przywołując okres przełomu lat 60. i 70, kiedy zapowiadałem się jako niezły napastnik i chciałem życie poświęcić graniu, graniu, graniu. Ówczesne lata to futbol amatorski, przaśny z dzisiejszej perspektywy, ale spontaniczny i angażujący młodych adeptów w pełni. Nikt jeszcze nie myślał o jakichkolwiek „szkółkach piłkarskich”, ogólnokrajowym naborze, a żaden z polskich zawodników pierwszej ligi nie miał szans na jakąkolwiek karierę zagranicą (zarówno na Zachodzie, jak i Wschodzie podzielonego kontynentu). Graliśmy więc na okrągło w „strefie przepływów” peryferii świata, przymierzając ambicje do lokalnych realiów A-klasy, B-klasy, ligi okręgowej, wojewódzkiej etc. Na tych najlepszych i najbardziej zdeterminowanych czekały w Poznaniu, w którym żyłem, kluby w miarę profesjonalne - Lech, Olimpia i Warta, wówczas jednak co najwyżej drugoligowe. Miasto pokryte było wszakże gęstą siatką klubów robotniczych i towarzystw sportowych; wystarczyło przyjść (na początku, a jakże, z własnym sprzętem) i zacząć trenować z rówieśnikami, albo z grającymi po pracy robotnikami dziesiątków państwowych zakła- 
dów pracy. W ten sposób - jednocześnie! - trenowałem w takich klubach, jak Surma, Energetyk i San, by później wyprawiać się na Golęcin do Olimpii i na Dębiec, gdzie zaczepiłem się w juniorach młodszych Lecha. Można powiedzieć, że „gra była mną", wszechogarniającą pasją, zwykle z minimalnym udziałem widowni - byłem klasycznym przykładem piłkarza z epoki paleofutbolu w jego czystej postaci. Unio mystica na lokalną miarę. Niekiedy nawet w dosłownym sensie, kiedy to grając na boisku Robotniczego Towarzystwa Sportowego „San”, wygospodarowanego na terenie dawnego cmentarza ewangelickiego w Poznaniu, w pewnym momencie, gnając lewym skrzydłem ku bramce, wpadłem do niemieckiego grobu, bo zarwała się murawa... Był rok 1969 (Burszta 2012: 8-9).

Niestety, dostawszy się z ledwością, z dużą pomocą znajomości ojca, do liceum, dowiedziałem się, że będę podlegał nowatorskiemu programowi nauczania, autorstwa ówczesnego ministra oświaty i wychowania, Jerzego Kuberskiego. Polegał on na wprowadzeniu idei ocen semestralnych, tak jak na studiach, i „dwuzmianowości” lekcji. Klasy dzieliły się także na te, które „szły” w normalnym trybie czteroletnim i „kuźnie talentów”, gdzie edukacja trwała dwa lata i wiązała z automatycznym przyjęciem na wybrany kierunek studiów. Nie muszę dodawać, jak traktowaliśmy tych drugich, jaką pogardą byli oni otoczeni ze strony normalsów, jakbyśmy dzisiaj powiedzieli. Notabene, prawie żadna z tych osób nie zrobiła szczególnej kariery, w przeciwieństwie do wielu z nas, których nie chciano „hodować” w trybie brojlerów socjalistycznej wiedzy.

Jako uczniowie najgorszej z pierwszych klas, I E, złożonej z „odpadów” edukacyjnych z całego miasta, przydzielono mi lekcje w systemie popołudniowym, co doskonale wykluczyło możliwość trenowania w Lechu. A miałem do ówczesnego stadionu na Dębcu ledwie dwa przystanki tramwajem. Po raz pierwszy odczułem cień, jaki rzucił na mnie PRL. Moja świadomość absurdów socjalizmu od tego się właśnie zaczęła - od osobistego zawodu, że Państwo przeszkadza mi w tym, co dla mnie najważniejsze. Od tego momentu inaczej zacząłem spoglądać na otaczający mnie świat. Oznaczało to zwrot zasadniczy - ku książkom i zainteresowaniom światem kultury.

Wiele w tym względzie zawdzięczam, zmarłemu przedwcześnie w roku 2005, mojemu rówieśnikowi i przyjacielowi „od zawsze”, Włodkowi Filipkowi, z którym wychowywałem się jako dziecko we wspólnej kamienicy na ulicy Gwardii Ludowej. Po moich przenosinach z dzielnicy Wilda na Grunwald, na lata straciliśmy kontakt, ale spotkaliśmy ponownie w niesławnej I E w liceum i odnowiliśmy więzi. Włodek, poznański Żyd, był encyklopedią wiedzy, osobowością niepokorną, zadziorną i zachłanną na życie. Dzięki niemu zainteresowałem się historią i historią sztuki, wspólnie kupowaliśmy radzieckie albumy z malarstwem, czytaliśmy klasykę literatury francuskiej i rosyjskiej, kłóciliśmy o wszystko. To on przygotował mnie do zdania matury z historii, a później, już w latach studenckich, wciągał w opozycyjną działalność na UAM, a jako ściśle związany z KOR - zlecał różne zadania 
związane z dystrybucją niezależnej prasy i książek. Ale przede wszystkim - wspólnie znaleźliśmy ucieczkę od beznadziei epoki gierkowskiej w niezależnym myśleniu i kształceniu wyobraźni. Wiedza stała się ekspiacją, oczyszczeniem z rzeczywistości.

Na te lata przypada także, radośnie odnotowane przez mojego ojca, zainteresowanie domową biblioteką i klasyką antropologii, filozofii i socjologii. Latami niewzbudzające mojego zainteresowania książki, nagle objawiły swój czar i powab. Pojawiły się marzenia o innym życiu, w innym miejscu, które - jak myślałem może być także innym czasem. 0 tym też po latach pisałem w jednej z gazet, czyniąc pretekst do opowieści bardziej współczesnej:

„Otóż kiedy byłem małym chłopczykiem - opowiada Marlow z Jądra ciemności Josepha Conrada - miałem namiętność do map. Wpatrywałem się godzinami w Południową Amerykę lub Afrykę, lub Australię, pogrążając się we wspaniałościach odkrywczych podróży. W owych czasach było jeszcze wiele pustych miejsc na ziemi, a jeśli które z nich wydawało mi się szczególnie ponętne (ale one wszystkie tak właśnie wyglądają), kładłem na nim palec i mówiłem: «Pojadę tam, jak dorosnę»".

Wielu z nas, żyjących sto lat po tamtych czasach, ma nadal w pamięci te wspaniałe dziecięce rojenia, że oto i my staniemy się odkrywcami takich dziewiczych miejsc. Palec i oko wędrowało chętnie tam zwłaszcza, gdzie na mapie brak było punkcików oznaczających miasta, a więc w wysokie góry lub przepastne knieje, na oceaniczne wysepki i archipelagi o dziwnych nazwach. Wiara, że właśnie nam przydarzy się to niebywałe, towarzyszy nam właściwie przez całe życie, inaczej jedynie przykrawamy swe ambicje, bo już lepiej wiemy, czego chcielibyśmy doświadczyć i czym się zachwycić. Aliści, idea podróży z domu ku obcym światom ma się dobrze! Cóż z tego, że wszystko już zostało poznane, ostatni prawdziwy „dziki”, ostatnia samotna wioska w buszu i ostatni szczęśliwi wieśniacy, którzy żyją własnym rytmem. Dopóki bowiem nie ruszę się fizycznie z miejsca, „tamten świat” jakby nie istnieje naprawdę, dopiero gdy go dotknę osobiście, wiedzieć będę, że obcuję z rzeczywistością inną od tej, w której poruszam się na co dzień, oswojoną i zwykłą.

Dzisiaj wszakże w ogromnej mierze telewizyjne ekrany zastąpiły tradycyjne, papierowe mapy i atlasy świata. To tutaj na naszych oczach rozciąga się panorama wielokulturowego świata, z wszystkimi jego okrucieństwami i pięknem w równej mierze. Niebywałe powodzenie programów i kanałów tematycznych poświęconych podróżom jest tego najlepszym dowodem. Dzisiejszy świat jest bardziej do oglądania niż mozolnego poznawania na podstawie zapisanych dokumentów. Potęga obrazu powoduje także, że nasza świadomość napędza się setkami wizualizacji, które kształtują zarówno naszą wyobraźnię, jak i wyznaczają horyzont konkretnych oczekiwań związanych z realną podróżą. Tam jest pięknie, tam chcę zabrać najbliższych, to jest to. Ale właśnie, jak to właściwie jest? Czy na- 
miętne oglądanie seryjnie produkowanych programów, których zadaniem jest dostarczenie wiedzy o inności kulturowej, zachęca do inicjatywy podjęcia podróży, choćby w najbardziej turystycznym, skonwencjonalizowanym sensie? A może takie programy są po prostu namiastką tego, czego doświadczyć nie zdołamy, nie możemy, albo wręcz nie chcemy?

Jeśli uświadomimy sobie, że globalny przemysł turystyczny to najbardziej dzisiaj dochodowa i najszybciej rozwijająca się gałąź ekonomii, warto zadać sobie pytanie o to, jaka jest rola telewizji oferującej programy podróżnicze, która - przedstawiając dziwy świata i jego kulturowe bogactwo - dostarcza niewątpliwie wiedzy, której onegdaj szukać trzeba było mozolnie na kartach książek i w trudno dostępnych albumach, co wiązało się z trudem intelektualnym i decyzją: czego mianowicie poszukuję. Teraz nie ma szukania po omacku, wszystko jest dostępne i tylko od mojej własnej decyzji zależy, która część świata zda się tą właśnie, do której warto byłoby się udać osobiście. Ale znowu wzbudźmy podejrzenia. Tylko w jakim charakterze?

W tym momencie dotykamy delikatnej kwestii związku pomiędzy „czystą", intelektualną potrzebą poznawania świata, do której zachęcać winny edukacyjnie „misyjne” kanały poznawczo-podróżnicze, a komercyjnie motywowaną turystyczną zachętą, że ten świat, pięknie wyglądający na ekranie, może być twój, bo ty możesz tam się udać! Żeby nie być gołosłownym: w momencie, kiedy piszę ten tekst, w mojej internetowej poczcie pojawiają się kolejne oferty firm, których naczelnym hasłem jest perswazja, abym zaplanował najbliższe wakacje, koniecznie w takich dekoracjach, o których skądinąd opowiadają obrazami kanały w rodzaju Discovery. Tylko od moich możliwości finansowych zależy, jaki wariant - tutaj cytuję przypadkowo dobrany tytuł serii wydawniczej - „Twoich wakacji i podróży marzeń" mi odpowiada.

Świat pokazany, czy to w postaci zdjęć czy bardziej złożonych sekwencji narracji obrazowej, zawsze miał tę przewagę nad słowem, opowieścią i oralną autorską relacją, że nie odwołuje się do środków głównie intelektualnych i nie wymaga koniecznie umiejętności budowania z przekazu własnego wyobrażenia tego, o czym mowa; że daje nam świat na talerzu, gotowy niejako. Wierzymy wizualności bardziej niźli słowu, a geograficzna mapa ma postać DVD. Mapa była do poznawania, DVD jest do odtwarzania. Jeśli dodatkowo, a tak przecież się dzieje, obraz zaopatrzony jest w wiarygodny komentarz, jest sygnowany znanym nazwiskiem osoby, która wzbudza nasze zaufanie, już dokonuje się to najważniejsze: rodzi się pasja uczestnictwa i chęć, aby pojechać tam, gdzie wszystko jest inne i ciekawe, na pewno ciekawsze od naszego - mimo wszystko - dnia codziennego, kiedy wyglądamy jak inni, mimo iż tego bardzo nie chcemy. Podróż obiecuje odmienność także nas samych!

Jakże ważne jest dzisiaj - zewsząd o tym słyszymy - abyśmy mieli styl życia. Nie wystarczy po prostu żyć i zmagać się z codziennością, trzeba jeszcze manifestować, że ma się pomysł na życie. A ten jest związany 
z kolekcjonowaniem wrażeń, realnym byciem „tam”, a nie jedynie obserwowaniem innych kultur i ludzi z pozycji widza. Jednym z niezbywalnych elementów tak kształtowanego stylu życia jest nakaz sezonowego przemieszczania się w realia maksymalnie odmienne od tych, w których można nas spotkać w ciągu roku, Po to są, między innymi, programy telewizji podróżniczych, oferujące szeroką gamę możliwości, gdzie umieścić tegoroczne ambicje podróżnicze - dzisiaj jest to ten obszar świata, jutro pewnie będzie passè, ale liczy się ruch, przemieszczanie się, dawanie do zrozumienia, że żaden zakątek świata nie umyka naszej uwadze. A dla mniej uprzywilejowanych pozostaje nadzieja, że z tego ciastka, którym jest ziemski glob, coś jeszcze zostanie do skonsumowania w momencie, kiedy i nam zacznie sprzyjać fortuna (Burszta 2008: 2; wyróżnienia w oryginale).

Antropologia, w swoim klasycznym wydaniu z książek Malinowskiego, Levi-Straussa czy Benedict, rozszerzała pojęcie możliwych światów, budowała wizję azylu, w którym życie wygląda inaczej. W czasach Gomułki, a później Gierka, kiedy realne możliwości podróży były wielce ograniczone, antropologiczny świat dziwów był jak objawienie. Nie zastanawiałem się wówczas, czy on jeszcze istnieje w opisanym kształcie, ważne, że mogłem go doświadczać na mocy - nie waham się tak napisać - lektury organoleptycznej. Sięgnąłem także po klasykę polskiego ludoznawstwa i etnografii, zagłębiłem w realia wsi XIX w., zaczytywałem w słownikach gwary i dialektów - słowem, amatorsko i po omacku budowałem zręby antropologicznej wyobraźni. Ona stała się panaceum na podwojony cień, który nieustannie mnie otaczał, była rodzajem eskapizmu od rzeczywistości. Z pewnością jednak antropologia była ucieczką od cienia PRL, podróżą w wyobrażone światy, gdzie wszystko jest możliwe.

Zdawszy maturę, ku przerażaniu ojca, który ciągle nie dowierzał, że „będą ze mnie ludzie", zdecydowałem się zdawać na studia etnologiczne w Poznaniu. Był rok 1975 i moje życie w podwojonym cieniu stało się także życiem zapośredniczonym przez wyobraźnię antropologiczną. Życiem na własny rachunek, wkroczeniem w dorosłość prawdziwą i własne starzenie się jednocześnie. Idąc na egzaminy wstępne, czytałem, jak zwykle, Pavese'a i do dzisiaj znam nieomal na pamięć ten fragment, który stał się także pretekstem do niniejszych zapisków. A brzmi on tak:

Starość - lub dojrzałość - opuszcza się również na świat zewnętrzny, mroźna i jasna noc zimowa, uwypuklająca domy na tle nieba, co czeka na śnieg, kiedyś dotykała samego serca i otwierała świat niepokojów heroicznych.

Z czasem przestaje być potrzebą poruszanie się w świecie zewnętrznym, przeżywanie jego niepokojów, wystarczy jakiś jego przelotny znak, świadomość, że istnieje i że istnieje w nas, abyśmy mogli oddać się światu całkowicie ukształtowanemu z faktów życia wewnętrznego, który od natury zdążył już przejąć to, co nowe i zapładniające. Dojrzałość jest również 
tą oto rzeczą: nie szukać już na zewnątrz, lecz pozwolić, by przemówiło, z właściwym mu rytmem, który się tylko liczy, życie wewnętrzne. Ubogi i zmaterializowany jest odtąd świat zewnętrzny w porównaniu z nieoczekiwanie głęboką dojrzałością wspomnień. Nawet krew i ciało nasze dojrzały, nasiąkły duchowością, tętnią żywym rytmem.

Młodość to nieposiadanie własnego ciała ani światła (Pavese 1972: 198; podkr. W. J. B.).

Dodałbym - dojrzałość to jednak także świadomość, że dzieciństwo i młodość mogą nie mieć ciała i światła, ale mają nieswoje cienie. Z nimi wkroczyłem w dorosłość i to one wyznaczają nadal trajektorię życia „dojrzałego”. To w nim doświadczyłem końca PRL i zostawszy bez rodziców na dobre, zacząłem budować zręby odpowiedzialności za siebie i innych. Ale to już osobna opowieść.

\section{Bibliografia}

Bauman Z., Kubicki R., Zeidler-Janiszewska A. (2009) Życie w kontekstach. Rozmowy o tym, co za nami i o tym, co przed nami, Warszawa, Wydawnictwa Akademickie i Profesjonalne.

Burszta W. J. (2008) Palcem po ekranie, „Gazeta Telewizyjna”, nr 149.

Burszta W. J. (2012) Postfutbolowa aura w: Postfutbol. Antropologia piłki nożnej, M. Czubaj, J. Drozda, J. Myszkorowski (red.), Gdańsk, Wydawnictwo Naukowe Katedra.

Kalbarczyk A. (2004) Cień jako biblijna metafora znikomości ludzkiego życia, „Poznańskie Studia Teologiczne", nr 16.

Lacan J. (2013) Imiona-Ojca, tłum. T. Gajda, J. Kotara i in., Warszawa, Wydawnictwo Naukowe PWN.

Pavese C. (1972) Rzemiosło życia (Dziennik 1935-1950), tłum. A. Dukanović, Warszawa, Państwowy Instytut Wydawniczy.

Ricoeur P. (2003a) Krytyka i przekonanie. Rozmowy z François Azouvim i Markiem de Launay, tłum. M. Drwięga, Warszawa, Wydawnictwo KR.

Ricoeur P. (2003b) O sobie samym jako innym, tłum. B. Chełstowski, Warszawa, Wydawnictwo Naukowe PWN.

Vonnegut K. (2013) Rzeźnia numer pięć, tłum. L. Jęczmyk, Warszawa, Albatros. 